условиях рынка: проблемы адаптации и развития / В.Л. Александров, А. В. Перелыгин, В. Ф. Соколов. - СПб.: Судостроение, 2003. - 424 с.

14. Александровская Н. И. Производственный потенциал судоремонтных и судостроительных предприятий Украины с учетом их расположения / Н. И. Александровская, А. В. Кошарская, В. Д. Евдокимов // Зб. наук.праць ОМНУ. - 2009. - №1. - С. 111119.

15. Жихарева В. Умови ефективної реалізації інвестицій у розвиток флоту суднобудівних компаній України / В. Жихарева // Економічний аналіз. - 2010. №7. - C. 45-47.

16. Макогон Ю. В. Украина держава морская / Ю. В. Макогон, А. Ф. Лысый, Г. Г. Гаркуша, А. В. Грузин. - ДонНУ, 2010. - 393 с.
17. Пирожков С. Проблемы реализации транзитного потенциала Украины в контексте расширения ЕС и формирования ЕЭП / С.Пирожков, Д.Прейгер, И.Малярчук // Экономика Украины. - 2005г, - № 3. - С.4-19.

18. Integration of Ukraine into the world maritime complex [Електронний pecypc] / I.R. Iarmolovych, D.I. Iarmolovych // Економіка: реалії часу. - 2015. - № 1(17).-C.190-194.

19. H.Mäkinen.The Russian maritime industry and Finland/Electronic Publications of Pan-European Institute,2/2015.[Електронний ресурс] Режим доступу: http: // www.utu.fi/pei

20. Jean-Paul Rodrigue, Brian Slack .Intermodal Transportation and Containerization Authors.[Електронний ресурс] - Режим доступу: https://people.hofstra.edu

УДК 656.025.2(477)

\title{
РЕФОРМУВАННЯ І СУСПІЛЬНІ ЕФЕКТИ ПАСАЖИРСЬКИХ ПЕРЕВЕЗЕНЬ ЗАЛІЗНИЧНОЇ ГАЛУЗІ
}

\author{
Слагін Ю.В., к.е.н., доцент, \\ Проценко Н.О., махістр (УкрДУЗТ)
}

\begin{abstract}
Транспорт впливає на: здоров'я $i$ життя населення;стан атмосфери $i$ біосфери; раціональне використовування природних та енергетичних ресурсів; забезпечення сталого розвитку краӥни. Залізничні пасажирські перевезення для суспільства більш ефективні ніж автомобільні за рахунок значно менших «зовнішніх витрат» залізничного транспорту. Субсидування перевезень відповідає інтересам суспільства і економіки, адже призводить до зниження зовнішніх витрат(«витрат переливу») пасажирських перевезень; збільшення мобільності населення, сприяє підвищенню якості трудових ресурсів і якості життя населення, дає довготривалий макроекономічний ефект для усієї країни. Необхідна розробка законодавчого механізму субсидування пасажирських перевезень залізничним транспортом, який буде гарантувати збереження та розвиток пасажирського залізничного комплексу після ліквідації перехресного субсидіювання пасажирських перевезень.
\end{abstract}

Ключові слова: пасажирські перевезення, реформування залізничного транспорту, сталий розвиток, витрати суспільства, суспільні ефекти транспорту. 


\title{
РЕФОРМИРОВАНИЕ И ОБЩЕСТВЕННЫЕ ЭФФЕКТЫ ПАССАЖИРСКИХ ПЕРЕВОЗОК ЖЕЛЕЗНОДОРОЖНОЙ ОТРАСЛИ
}

\author{
Елагин Ю.В., к.э.н., доцент, \\ Проценко Н.А., магистр (УкрГУЖТ)
}

\begin{abstract}
Транспорт влияет на: здоровье и жизнь населения; состояние атмосферы $и$ биосферы; рачиональное использование природных и энергетических ресурсов; обеспечение устойчивого развития страны. Железнодорожные пассажирские перевозки для общества более эффективные чем автомобильные за счет значительно меньших «внешних издержек» железнодорожного транспорту.Субсидирование перевозок отвечает интересам общества и экономики,приводит к снижению внешних издержек ( «расходов перелива») пассажсирских перевозок; увеличению мобильности населения, способствует повышению качества трудовых ресурсов и качества жизни населения, дает длительный макроэкономический эффект для всей страны. Необходима разработка законодательного механизма субсидирования железнодорожных пассажирских перевозок транспортом, который будет гарантировать сохранение и развитие пассажирского железнодорожного комплекса после ликвидации перекрестного субсидирования пассажирских перевозок.

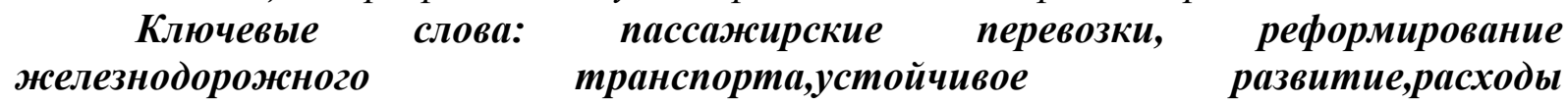
общества,общественные эффекты транспорта
\end{abstract}

\section{REFORM AND PUBLIC EFFECTS OF PASSENGER TRANSPORTATION OF THE RAILWAY INDUSTRY}

\author{
Yelagin Yu.V., Candidate of Economic Sciences, Associate Professor, \\ Protsenko N.A., Master (USURT)
}

Transport affects: health and life of the population; state of the atmosphere and the biosphere; rational use of natural and energy resources; ensuring sustainable development of the country. Railway passenger transportation for the society is more efficient than automobile ones at the expense of considerably less "external costs" to the railway transport. Subsidizing transportations meets the interests of society and the economy, leading to a reduction in external costs ("overflow costs") of passenger transportation; Increasing the mobility of the population, contributing to the improvement of the quality of labor resources and the quality of life of the population, gives a lasting macroeconomic effect for the whole country. It is necessary to develop a legislative mechanism for subsidizing passenger transportation by rail, which will guarantee the preservation and development of the passenger railway complex after the elimination of cross subsidization of passenger traffic.

Keywords: passenger transportation, railway transport reform, sustainable development, society costs, public transport effects

Постановка проблеми. Для спостерігається постійне: зростання залізничної галузі в умовах реформування обсягів пасажирських перевезень та їх підвищується актуальність та важливість збитковості, зростання конкурентного вирішення задачі фінансування тиску у секторі пасажирських перевезень 3 пасажирських перевезень, оскільки боку перевізників автомобільного

Вісник економіки транспорту і промисловості № 58, 2017 
транспорту. Для нормального функціонування, а тим більше розвитку пасажирських перевезень необхідно вирішувати проблему їх збитковості та забезпечити необхідний рівень фінансування 3 дотриманням належного рівня якості та безпеки [4].

Аналіз останніх досліджень та публікацій. Питання підвищення ефективності залізничних пасажирських перевезень розглядали в своїх роботах такі вчені як Ю.С. Бараш [1], О.М. Гудков, В.П. Гудкова [3], В.Л. Дикань [5], Г.Д. Ейтутіс [8], Чаркіна Т.Ю [9] та багато інших. У якості основних шляхів підвищення ефективності пасажирських перевезень більшість авторів, так чи інакше розглядають необхідність підвищення тарифів та різні організаційно- технологічні напрямки підвищення ефективності, проблеми субсидування збитків із державного та місцевих бюджетів.

Разом 3 тим питанням перехід в умовах реформування залізничного транспорту до сучасних підходів оцінки ефективності пасажирських перевезень с точки зору сталого розвитку економіки країни та усього суспільства взагалі приділяється недостатньо уваги. Не повною мірою враховується, що розвиток доступних для всього населення якісних залізничних пасажирських перевезень сприяе економічному прогресу, підвищенню якості трудових ресурсів і якості життя населення.

Мета статті - дослідження ефективності для суспільства розвитку того чи іншого виду пасажирських перевезень 3 точки зору сталого розвитку, суспільних витрат та ефектів для економіки країни та усього суспільства.

Виклад основного матеріалу. Основною метою реформування залізничного транспорту у пасажирському секторі $\epsilon$ розвиток конкуренції; створення умов для залучення інвестицій у розвиток пасажирських перевезень; організація прозорого формування витрат і ліквідація перехресного субсидіювання пасажирських перевезень за рахунок вантажних; забезпечення державної підтримки збиткових видів перевезень i підвищення ефективності діяльності галузі.

3 огляду на існуючу багаторічну практику недофінансування державними органами перевезень пільгових категорій пасажирів, передбачена програмою реформування ліквідація перехресного субсидування і виділення пасажирських перевезень в окрему компанію створить ризики неотримання дотацій i зниження обсягів пасажирських перевезень.

У світовій практиці перевезення пасажирів залізничним транспортом у внутрішньому i особливо регіональному сполученні є збитковим видом діяльності. Для його функціонування i розвитку потрібна фінансова підтримка. У тих державах, де припинена практика перехресного субсидування пасажирських перевезень за рахунок вантажних, обов'язково здійснюється фінансова підтримка за рахунок держави. Там, де така підтримка була припинена, суттево зросла вартість квитків, скоротилось оновлення основних фондів, підвищилась кількість аварій, скоротились обсяги перевезень пасажирів.

Розвиток залізничного транспорту в Європі регламентується так званим залізничним пакетом директив $\mathrm{EC}$. Найважливішою 3 них вважається директива 91/440 яка присвячена управлінню і розвитку мережі залізниць, відповідно до якої будь-яка реформа може проводитися тільки за умови подальшого економічного оздоровлення залізниць. Якщо при цьому залишаються нерентабельні галузі, які виконують соціально значущі функції, то вони повинні отримати підтримку зацікавлених сторін, в тому числі держави. Причому пасажирські оператори мають пріоритет на отримання субсидій в порівнянні 3

Вісник економіки транспорту і промисловості № 58, 2017 
вантажними перевізниками. Крім того, додаткові субсидії можуть бути виділені при необхідності на забезпечення безпеки пасажирських перевезень. За директивам ЄC, загальна вартість куплених квитків повинна покривати не менше 35\% витрат перевізника за контрактом із замовником. За останні 20 років кількість перевезених пасажирів на поїздах в Свропі зростає рекордними темпами. У Великобританії цей показник збільшився на 70\%, в Швеції - на 42\%, у Франції та Бельгії - на 37\% і 26\% відповідно.

За статистичними даними в країнах $€ C$ щорічно витрачається понад $€ 36$ млрд. на покриття збитковості пасажирських перевезень. В Німеччині загальні субсидії залізницям складають $€ 7-14$ млрд., у Франції - €11, в Італії - €8 млрд. Для порівняння збитковість пасажирських перевезень на залізницях України в 2013 p. склала $€ 0,3$ млрд. На сьогодні в Норвегії 3 держбюджету покривається 50\% вартості пас.перевезень, в Данії - 48\%, Франції $42 \%$. В Італії, Німеччині, і навіть у новій країнах СС - Чехії та Болгарії пасажири оплачують близько $70 \%$ від вартості поїздки, інше компенсує бюджет. Лише у Великобританії та Нідерландах пасажир оплачує майже повну вартість квитка. I Великобританія $є$ показовим прикладом невдалих реформ на залізничному транспорті. Адже після тотальної приватизації залізниць, у т.ч. залізничних колій та іншої інфраструктури підвищилась кількість аварій, скоротилось оновлення основних фондів, значно зросла вартість квитків.

У Німеччині реформа регіональних пасажирських перевезень вважається найбільш ефективною: вона допомогла збільшити пасажирооборот на третину при зростанні субсидій держави всього на 15\%. Німеччині вдалося найбільш повно виконати і вимога регіоналізації субсидій. Дотації виділяються 3 федерального бюджету, але розпоряджаються ними регіони - землі: саме вони формують замовлення на перевезення, встановлюють маршрути, обсяг, частоту перевезень і тип рухомого складу, цінову пропозицію, а також проводять тендери серед операторів i укладають 3 ними довгострокові договори на надання послуг, не менше ніж на п'ять років.

Держрегулювання тарифів регіональних перевезень здійснюється в рамках доплат і субсидій: якщо потрібно стримати зростання тарифів, відповідно збільшується державна підтримка. При цьому доходи операторів утворюються не тільки від продажу квитків на поїзди, а й від реалізації додаткових послуг, які, до речі, в 1,8 рази перевищують надходження від продажу квитків. Державні залізниці Італії з 1999 року були розділені на дві компанії, одна 3 яких взяла функції перевізника (ВАТ «Треніталія»), а інша управління інфраструктурою (ВАТ «Італійська залізнична мережа»). Після того як регіональні перевезення перейшли до компетенції обласних адміністрацій, на мережі з'явилося понад чотирьох десятків приватних операторів.

В Італії загальна вартість куплених квитків покриває в середньому - 37\% витрат на перевезення пасажирів. Однак по різних регіонах він цей показник нерівнозначний: регіон може мати звичайний або спеціальний статус. На економічно розвиненій півночі Італії 3 інтенсивним пасажиропотоком окупається 75\% пасажирських перевезень, а на бідному півдні Італії, навпаки, три чверті обсягу перевезень фінансуються державою. При цьому на півдні країни залізничний квиток коштує в середньому на 20\% дешевше, ніж на півночі. Всі дотації для залізничних мереж надходять безпосередньо 3 федерального бюджету. Якщо маршрути перетинають сусідні області, то дотації діляться між ними.

В цілому ж в Італії використовують всі види дотацій, які передбачені в директивах ЄС. В iї національних законах окремим рядком прописані, наприклад, інвестиції для розвитку регіональних перевезень. Крім того, залізничники

Вісник економіки транспорту і промисловості № 58, 2017 
отримують кошти на забезпечення безпеки руху, а перевізники - на оновлення рухомого складу. Правда, величина останніх двох видів субсидій залежить від загальних доходів італійського бюжету.

Такі факти дають підставу стверджувати, що залізничний транспорт потребує державної підтримки за визначенням. Субсидіювання перевезень відповідає загальноєвропейській практиці, адже призводить до збільшення мобільності населення та дає довготривалий макроекономічний ефект для розвитку усієї країни. Ефективність залізниць не можна вимірювати лише показниками рентабельності.[ 8]

В сучасних умовах оцінюючи варіанти реформування і розвитку сектору залізничних пасажирських перевезень України не можна нехтувати вимогами сталого розвитку суспільства. Концепція сталого розвитку, прийнята у 1992р. полягає у задоволенні потреб суспільства 3 одночасним збереженням можливостей наступних поколінь i проголошує необхідність збалансування економічних, екологічних та соціальних інтересів теперішніх та майбутніх поколінь шляхом створення соціально-орієнтованої економіки, яка спирається на раціональне використання природних ресурсів та на охорону навколишнього середовища. Транспорт істотно впливає на оточуючу середовище i суспільство через аварії, забруднення атмосфери, шум i iнші чинники. Якщо говорити про роль транспорту в забезпеченні сталого розвитку суспільства, то необхідно зазначити що транспорт впливає на: здоров'я і життя населення; забезпечення сталого розвитку населених пунктів; захист атмосфери i біосфери; раціональне використовування природних та енергетичних ресурсів [7].

Проблема оцінки впливу транспорту на навколишне середовище знаходить відображення у вимірі зовнішніх витрат транспорту. Зовнішні витрати(«Витрати переливу» ) - побічні витрати виробництва товарів і послуг, які несуть не виробники і споживачі, а населення і суспільство в цілому без будь-якого відшкодування. Стосовно транспорту - це витрати від функціонування транспорту які несуть населення i суспільство в цілому без відшкодування. Сутність їх полягає в тому, що транспортні підприємства сплачують тільки власні експлуатаційні витрати. Негативний вплив транспортної одиниці під час такої поїздки на навколишне середовище, витрати на ліквідацію аварій та інші витрати суспільства при цьому сплачує все суспільство. Оці додаткові витрати, які лягають на все суспільство, і є зовнішніми витратами або «витратами переливу».

Наприклад, в країнах Євросоюзу ведеться моніторинг оцінки шкоди, яку завдають суспільству різні види транспорту. Крім того, для країн Свросоюзу періодично розраховуються середньорічні загальні та питомі витрати на боротьбу зі шкідливими наслідками від транспорту окремо за різними факторами (аварії, шум, забруднення повітря, зміна клімату, вплив на природу, міські та індустріальні ефекти).

На теперішній час в Україні не ведеться облік та оцінка зовнішніх витрат та ступіню шкідливого впливу окремих конкуруючих видів пасажирського транспорту. Цє не дозволяє повною мірою оцінити та порівняти загальні витрати на перевезення пасажирів 3 урахуванням всіх зовнішніх витрат, які сплачує все суспільство за перевезення пасажирів різними видами транспорту. Однак у роботах [1,9] наведені результати досліджень, які стверджують витрати суспільства на перевезення пасажирів залізничним транспортом у 2-10 разів менші ніж автомобільним. Найбільша ж різниця витрат суспільства спостерігається по таких категоріях зовнішніх витрат, як забруднення атмосферного повітря шкідливими викидами та завдання шкоди життю і здоров'ю людей у аваріях. 
Розподіл витрат на боротьбу зі шкідливими наслідками (Джерело: [9])

\begin{tabular}{|l|c|c|}
\hline \multirow{2}{*}{ Фактор } & Вартість витрат на боротьбу зі шкідливими наслідками \\
\cline { 2 - 3 } & млрд євро & відсотки \\
\hline Аварії & 156 & 24 \\
\hline Шум & 46 & 7,1 \\
\hline Забруднення повітря & 175 & 27 \\
\hline Зміна клімату & 196 & 30,1 \\
\hline Вплив на природу & 20 & 3,1 \\
\hline Міські ефекти & 10 & 1,5 \\
\hline Індустріальні ефекти & 47 & 7,2 \\
\hline Всього & 650 & 100 \\
\hline
\end{tabular}

Варто зазначити, що при порівнянні ефективності для суспільства доцільності фінансування розвитку того чи іншого виду пасажирських перевезень слід враховувати не тільки потрібні інвестиції в транспортну інфраструктуру а і очікувані витрати суспільства. Суспільство отримує довгостроковий економічний ефект, інвестуючи у розвиток транспортної інфраструктури пасажирських перевезень с нижчими зовнішніми витратами. Тож залізничні пасажирські перевезення для суспільства більш ефективні за рахунок значно менших зовнішніх витрат залізничного транспорту.

Крім ефекту «зовнішніх витрат» пасажирського залізничного транспорту, слід зазначити і ряд ефектів пов'язаних 3 доступними тарифами для всіх верств населення України, як країни 3 низьким рівнем доходів основної маси населення. Доступність залізничного пасажирського транспорту веде до підвищення рухливості населення. Високий рівень рухливості населення, в свою чергу забезпечує більш повне використання робочої сили, перерозподіл іiі між індустріальними центрами і освоюваними територіями, сприяючи економічному прогресу, підвищенню якості життя населення та якості трудових ресурсів:сприяє економічному, соціальному i культурному розвитку населення i iнтеграції між регіонами;формується доступність тих чи інших районів розселення, вибору місць роботи, навчання і відпочинку; більш раціонально використовуються трудові ресурси, основні виробничі фонди завдяки введенню швидкісного сполучення i збільшення радіусів територій, 3 яких трудові ресурси залучаються до виробництва.

Всі ці ефекти обумовлюють необхідність розробки механізму субсидування внутрішньодержавних пасажирських перевезень залізничним транспортом, який буде гарантувати забезпечення державної підтримки збиткових пасажирських перевезень після ліквідації перехресного субсидіювання пасажирських перевезень.

\section{Висновки i перспективи}

подальших досліджень Варто визначити роль транспорту в забезпеченні сталого розвитку суспільства. Транспорт впливає на наступні області: здоров'я i життя населення; захист атмосфери і біосфери; раціональне використовування природних та енергетичних ресурсів; забезпечення сталого розвитку регіонів та краіни у цілому.

Залізничні пасажирські перевезення для суспільства більш ефективні ніж автомобільні за рахунок 
значно менших «зовнішніх витрат» залізничного транспорту. Субсидіювання перевезень відповідає інтересам суспільства і економіки, адже призводить до зниження зовнішніх витрат(«витрат переливу») пасажирських перевезень; забезпечує більш повне використання робочої сили; сприяє підвищенню якості трудових ресурсів i якості життя населення та дає довготривалий макроекономічний ефект для розвитку усієї країни.

В підсумку слід зазначити про необхідність розробки законодавчого механізму внутрішньодержавних субсидування пасажирських перевезень залізничним транспортом, який буде гарантувати збереження та забезпечення державної підтримки збиткових видів пасажирських перевезень після ліквідації перехресного субсидіювання пасажирських перевезень за рахунок вантажних та розвиток пасажирського залізничного комплексу.

\section{ПЕРЕЛІК ВИКОРИСТАНИХ ДЖЕРЕЛ}

1 Методичний підхід щодо вибору раціонального варіанту розвитку міських пасажирських перевезень / Ю. С. Бараш, Ю. П. Адамян // Вісник економіки транспорту і промисловості. Збір наук. праць - Харків, УкрДАЗТ, 2015 - № 49 с. 44-53.

2 Гудков, О.М. Перспективний механізм фінансування пасажирських перевезень на залізничному транспорті [Текст] / О.М. Гудков // Проблеми економіки транспорту: зб. наук. пр. - Д.: Вид-во Дніпропетр. нац. ун-ту залізн. трансп. ім. акад. В. Лазаряна, 2011. - Вип. 1. - C. 34-39.

3 Гудкова, В. Теоретико-прикладні основи підвищення ефективності економічної діяльності підприємств на ринку транспортного обслуговування населення [Текст] / В. Гудкова // Збірник наукових праць Державного економікотехнологічного університету транспорту: Серія «Економіка і управління». - Вип. 25. - К.: ДЕТУТ, 2013. - С. 11-28.

4 Дикань В.Л. Перспективи фінансування приміських пасажирських перевезень в умовах акціонування залізничного транспорту [Текст] / В.Л. Дикань, Ю.В. Слагін // Науковий вісник Міжнародного гуманітарного університету. Серія : Економіка i менеджмент. - 2016. - Вип. 16. - С. 4648.

5 Дикань, В.Л. Інформаційні технології підвищення ефективності пасажирських перевезень [Текст] / В.Л. Дикань, Ю.В. Слагін // Вісник економіки транспорту i промисловості: збірник наукових праць. - Харків: УкрДУЗТ. 2015. - Вип. 52. - С. 107-110.

6 Ейтутіс Г.Д. Стратегія реформування залізниць України на основі регіоналізації транспортного обслуговування [Текст]: дис...д-р. екон. наук: 08.00.03 / Ейтутіс Георгій Дмитрович;Рада по вивченню продуктивних сил України НАН України. - Київ, 2010.- 452 с.

7 Єлагін Ю.В. Проблеми сталого розвитку суспільного транспорту та суспільні транспортні витрати. [Текст] / Ю.В. Слагін // Вісник економіки транспорту і промисловості. Збір наук. праць - Харків, УкрДАЗТ, 2011 - № 35 с. 254-256

8 Полякова О.M. Особливості розвитку пасажирських перевезень на залізничному транспорті України / Полякова О.М., Іванченко Ю.В. // Вісник економіки транспорту і промисловості. 2017. - № 57. - С.91-97

9 Чаркіна Т.Ю. Управління конкурентоспроможністю залізничних пасажирських перевезень на ринку транспортних послуг : дис. ... канд. екон. наук / Т. Ю. Чаркіна. - Х. : УкрДАЗТ, 2013. $-256 \mathrm{c}$ 